\title{
MODELLING THE ENVIRONMENTAL AND BIOLOGICAL CUES FOR THE BLOOM OF SERGESTID SHRIMP Acetes (DECAPODA: SERGESTIDAE) IN COASTAL WATER OF MIRI, SARAWAK, MALAYSIAN BORNEO
}

\author{
ABANG MOHAMMAD HUDZAIFAH ABANG SHAKAWI ${ }^{*}$, MUHAMMAD NUR ARIF OTHMAN², \\ RUHANA HASSAN ${ }^{1,2}$ and CHEN CHENG ANN ${ }^{3}$ \\ ${ }^{1}$ Centre for Pre-University Studies, Universiti Malaysia Sarawak, \\ 94300 Kota Samarahan, Sarawak, Malaysia \\ ${ }^{2}$ Faculty of Resource Science and Technology, Universiti Malaysia Sarawak, \\ 94300 Kota Samarahan, Sarawak, Malaysia \\ ${ }^{3}$ Universiti Malaysia Sabah, 88400 Kota Kinabalu, Sabah, Malaysia \\ *E-mail: asamhudzaifah@unimas.my
}

Accepted 14 July 2021, Published online 31 December 2021

\begin{abstract}
The sergestid shrimp (Acetes spp.) shows the annual peak season from February to April. This krill-like shrimp, locally known as 'bubok', is one of the commercially important fisheries in Miri, Sarawak, Malaysian Borneo. Previous researchers had reported patchy data on the environmental factors and Acetes distribution in Miri-Bintulu adjacent areas. Moreover, insufficient analysis has led to the inability to conduct sustainable management strategies for Acetes fisheries. Therefore, this study is designed to explore the mathematical model usage to understand the interaction between selected water quality parameters and zooplankton assemblages with the Acetes population in the coastal water of Miri. Selected temporal biotic and abiotic data were collected using standard methods and later subjected to mathematical time series analysis called the Granger causality test. The results show bi-directional Granger causality between the abundance of Acetes and dissolved oxygen (DO). Interaction between other water quality parameters (temperature, salinity, turbidity, $\mathrm{pH}$, TSS and Chlorophyll a) with the abundance of Acetes has also emerged. The number of zooplankton in the water column, namely Centropages, Euterpina, Oithona rigida, and Oncaea shows a significant causality towards the abundance of Acetes. The findings imply that complex interaction between biotic and abiotic factors exists during the bloom of Acetes in Miri; thus, relevant agencies should step up measures to ensure sustainable management of the coastal areas where Acetes bloom occurs.
\end{abstract}

Key words: Granger causality, sergestid shrimp, water quality, zooplankton

\section{INTRODUCTION}

Coastal water is defined as a zone where land and water interact with each other (Moksness et al., 2013), serves as an important settlement area for human and home for various species of fishes, molluscs, prawns and crabs, providing natural foods for human as well as daily income for the locals (Srinivasan et al., 2013; Obatitor, 2014). Miri is a coastal city, located in the northwest part of Sarawak, Malaysia, which has an open coastline type facing the South China Sea, ranging from the mouth of Baram River until Tanjong

* To whom correspondence should be addressed.
Lobang beach (Ee \& Zae, 2010). Miri coastal water is made up of coral reef, seagrass, beach forest and mangrove, provides important fisheries such as skipjack tuna, Spanish mackerel, grouper and sergestid shrimp known as Acetes (Amin et al., 2010). Acetes spp. (local name: 'bubok') show peak season from February to April and this krill-like shrimp is commercially important in Miri (Anandkumar et al., 2017). Shrimp and its product could be sold as high as 12 USD per kilogram (Hassan \& Othman, 2021). The by-products of Acetes include 'belacan', a fermented shrimp paste and a pickle 'cincalok', are Malaysian local cooking ingredients. The fresh Acetes shrimps could be sold at approximately 0.8 
to 1 USD per kilogram especially during the peak season in February and March (Abdullah, 2018; Ringgit, 2019). Meanwhile, the fermented shrimp paste is sold at a range price of 12 to 17 USD per kilogram (Abdullah, 2019) Therefore, the presence of Acetes in Miri is generating income to both artisanal and commercial fishermen as well as the local people.

Acetes is commonly found in tropical and subtropical areas (Amin et al., 2012). Studies claimed that the distribution and abundance of Acetes are influenced by environmental factors, such as water temperature, salinity and type of sediment (Chiou et al., 2000; Calazans, 2002; Chen \& Chen, 2002; Simoes et al., 2013). According to Chiou et al. (2000), rainfall could trigger the swarming of $A$. intermedius at the surface water in southwest Taiwan where low salinity provides an optimum condition for its prespawning aggregation. An experiment done by Chen and Chen (2002) showed that A. intermedius in Kaohsiung harbour, Taiwan preferred estuary habitat with salinity between 25 to 30 PSU as its spawning ground. Chen and Chen (2002) also reported that the salinity of estuary between 20 PSU to 30 PSU showed a higher metamorphosis rate of nauplii into protozoea I of A. intermedius. Therefore, Acetes has different tolerance against salinity change in different regions and evidence shows salinity is closely related to the spawning period and growth rate of this shrimp (Calazans, 2002; Simoes et al., 2013).

Previous research on Acetes in Malaysian Borneo focused on the status of Acetes landing (Stephenie et al., 2021), checklist of Acetes (Othman et al., 2020), population structure and feeding habits (Saini, 2013), morphometric study (Musel et al., 2019) and molecular phylogeny (Hassan \& Othman, 2021). Lack of information documented on the environmental factors which could influence Acetes distribution had been highlighted by Saini et al. (2011) and Saini (2013). Interaction between biotic and abiotic factors is important to support the survival of a species and the overall health of an ecosystem (Molles \& Simon, 2019). The environmental complexity and the dynamics of coastal areas have become the challenges in modeling the yearly bloom of Acetes in Miri coastal water. Besides that, lack of scientific data and low phenomenon forecasting ability had hindered sustainable management of the resource. Other studies elsewhere for example by Childress (2015) had successfully forecasted other aquatic life which is crab fishery using real-time freshwater flow data that led to better management of freshwater discharge since overall landings will decline if discharge also continues to decrease over time. Therefore, this study was conducted to investigate the possible interaction between selected water quality parameters and the abundance of zooplankton towards the abundance of Acetes population in coastal water of Miri, Sarawak, using Mathematical time series analysis called Granger causality test.

\section{MATERIALS AND METHODS}

Study area
Monthly field samplings were conducted in
the coastal water of Kuala Baram and Batu 1, Miri,
Sarawak from May 2017 until April 2018. Four
stations were chosen and their coordinates were
recorded using Global Positioning System (GPSmap
62S, GARMIN). Table 1 shows the coordinates and
brief descriptions of each station. Table 2 shows the
weather and condition of water during the field
samplings. Figure 1 shows the location of the
stations involved in this study.
Physico-chemical parameters of water
Selected water quality parameters were measured
at approximately 0.5 meters below the surface water
during flooding tide at every station and triplicate
Brief descriptions

Monthly field samplings were conducted in the coastal water of Kuala Baram and Batu 1, Miri, Sarawak from May 2017 until April 2018. Four stations were chosen and their coordinates were recorded using Global Positioning System (GPSmap $62 \mathrm{~S}$, GARMIN). Table 1 shows the coordinates and brief descriptions of each station. Table 2 shows the weather and condition of water during the field samplings. Figure 1 shows the location of the

\section{ico-chemical parameters}

Selected water quality parameters were measured at approximately 0.5 meters below the surface water during flooding tide at every station and triplicate

Table 1. Coordinate and brief descriptions of each station

\begin{tabular}{|c|c|c|}
\hline Station & Coordinate & Brief descriptions \\
\hline 1 & $\begin{array}{l}\text { N } 04^{\circ} 33^{\prime} 50.4^{\prime \prime} \\
\text { E } 113^{\circ} 58^{\prime} 15.6^{\prime \prime}\end{array}$ & $\begin{array}{l}\text { - Near the mouth of Baram River } \\
\text { - Sandy beach } \\
\text { - Sea wall could be seen along the coastline }\end{array}$ \\
\hline 2 & $\begin{array}{l}\mathrm{N} 04^{\circ} 33^{\prime} 11.8^{\prime \prime} \\
\mathrm{E} 113^{\circ} 58^{\prime} 28.6^{\prime \prime}\end{array}$ & - Sandy beach \\
\hline 3 & $\begin{array}{l}\text { N } 04^{\circ} 31^{\prime} 27.4^{\prime \prime} \\
\text { E } 113^{\circ} 59^{\prime} 05.3^{\prime \prime}\end{array}$ & $\begin{array}{l}\text { - Located near a small river } \\
\text { - Tyre factory could be seen at the coast } \\
\text { - No beach, sea wall could be seen }\end{array}$ \\
\hline 4 & $\begin{array}{l}\mathrm{N} 04^{\circ} 29.796 " \\
\mathrm{E} 113^{\circ} 59.469^{\prime \prime}\end{array}$ & $\begin{array}{l}\text { - Located near Batu } 1 \text { jetty and fish market } \\
\text { - Beach absent, seawall could be seen along the coastline }\end{array}$ \\
\hline
\end{tabular}


Table 2. Weather and condition of water from May 2017 until April 2018

\begin{tabular}{lcl}
\hline Month & Monsoon & \\
\hline May 17 & SWM & Sunny \\
June 17 & SWM & Cloudy \\
July 17 & SWM & Cloudy \\
Aug 17 & SWM & Sunny, windy \\
Sept 17 & SWM & Cloudy \\
Oct 17 & M & Windy, rainy (inter-monsoon) \\
Nov 17 & NEM & Sunny \\
Dec 17 & NEM & Cloudy, strong wind (Tropical storm Kai Tak) \\
Jan 18 & NEM & Cloudy \\
Feb 18 & NEM & Cloudy \\
Mar 18 & NEM & Sunny \\
Apr 18 & M & Sunny \\
\hline
\end{tabular}

*NEM: northeast monsoon, SWM: southwest monsoon, IM: inter monsoon.

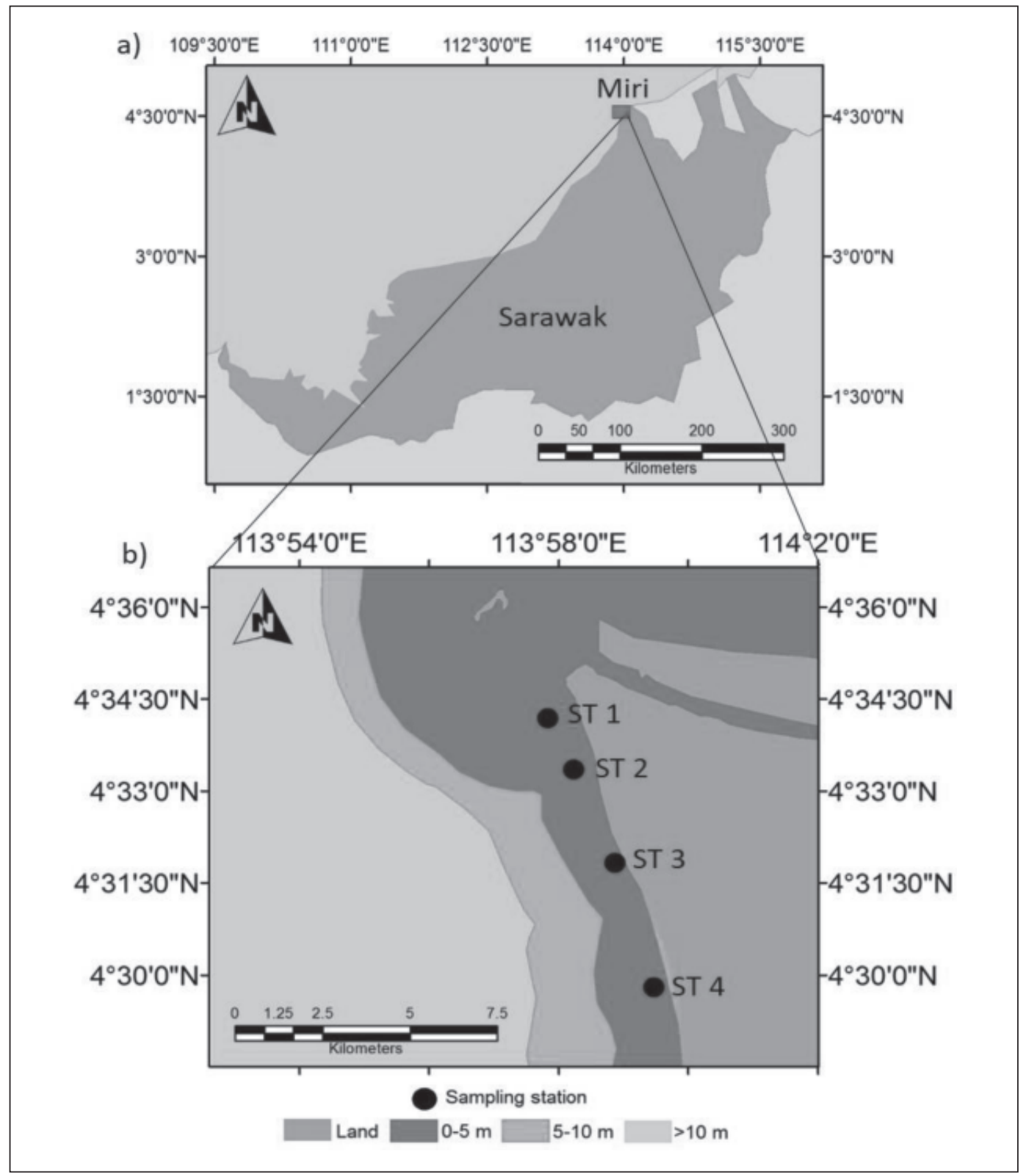

Fig. 1. (a) Map of Sarawak; (b) The black dot indicates the sampling stations in Miri, Sarawak (ST1-ST4). 
readings were recorded. The total number of data collected was 964 stations $\times 3$ replicates $\times 8$ sampling months. In this study, data could not be collected in July 2017, September 2017, October 2017 and January 2018 due to bad weather and rough sea condition. Dissolved oxygen (DO), temperature, turbidity, $\mathrm{pH}$, and salinity were measured in situ using DO meter (HI9146, Hanna Instrument), turbidity meter (TU-2016, Lutron), pH meter (HI 991003, Hanna Instrument), and refractometer (300011, Sper Scientific).

During the same fieldwork, selected ex situ water quality parameters namely chlorophyll $a(\operatorname{chl} a)$ and total suspended solids (TSS) were also obtained. Similar to in situ water quality parameters, the total data collected was 96. At each station, 2 litres of water samples were collected using a horizontal Van Dorn water sampler at approximately 0.5 meters depth from the surface of the seawater and stored in polyethylene bottles. All samples were kept in a cooler box with ice and brought back to the laboratory in Universiti Malaysia Sarawak (UNIMAS) for further analysis.

\section{Laboratory work}

Chl $a$ was analysed using the method proposed by Aminot and Rey (2000). A total of $500 \mathrm{~mL}$ of water sample was filtered through clean glass fibre filter paper (Whatmann, GF/C, $1.2 \mu \mathrm{m}$ pore size, $47 \mathrm{~mm}$ diameter) using an electrical filter pump. The wavelength of $630 \mathrm{~nm}, 647 \mathrm{~nm}, 664 \mathrm{~nm}$ and $750 \mathrm{~nm}$ were obtained using a spectrophotometer (DR 2800, Hach).

Total suspended solids (TSS) was analysed using the method proposed by Scannell and Jacobs (2001). A total of $500 \mathrm{~mL}$ of water sample was filtered through clean glass fibre filter paper (Whatmann, $\mathrm{GF} / \mathrm{C}, 1.2 \mu \mathrm{m}$ pore size, $47 \mathrm{~mm}$ diameter) using an electrical filter pump. Before filter, the filter paper was weighed using an analytical balance (Ohaus) to determine the initial weight (FS). The filter paper with samples was dried in the oven for 24 hours at $60^{\circ} \mathrm{C}$ followed by weighing to determine the final weight (FF). The standard protocol was used to calculate the TSS values.

\section{Acetes sampling}

The bottom trawl net was used to catch the Acetes at every station with aid from local fishermen. Samples were only available for May 2017, August 2017, November 2017, March 2018 and April 2018. Acetes could not be collected during other field trips due to bad weather, rough sea and the presence of wood fragments on the seabed which prohibit trawling activities. The net was towed by a boat with a speed of $2 \mathrm{~km} / \mathrm{h}$ for 15 minutes and two replicates of the collection were done. The total number of samples collected was 40 (4 stations $\times 2$ replicates $\times$ 5 sampling months). Approximately $200 \mathrm{~g}$ of samples were collected from every trawl, fixed in $10 \%$ formalin and brought back to the laboratory in the Faculty Resource Science and Technology, Universiti Malaysia Sarawak (UNIMAS) for further analysis. Identification of Acetes was based on species identification keys provided by Pathansali (1966), Omori (1975), Amin et al. (2011) and Vereshchaka et al. (2016).

\section{Plankton sampling}

Plankton net was used to collect the sample of zooplankton following methods by Al-Kandari et al. (2009). The volume of water sampled by the zooplankton net was calculated using the formula derived from Perry (2003) given as:

$$
\text { Volume }=\pi r^{2} L
$$

where

$$
\begin{aligned}
& r=\text { radius of net opening }\left(\mathrm{m}^{2}\right) \\
& L=\text { length of tow (boat speed } \times \text { time) }
\end{aligned}
$$

Two replicate samples of zooplankton were collected at every station using a zooplankton net with a mesh size of $100 \mu \mathrm{m}$. The net was towed horizontally, at depth of $0.5 \mathrm{~m}$ from the water surface, at the speed of 2.0 to $2.5 \mathrm{~km} / \mathrm{h}$ for 5 minutes. Therefore, the estimated volume of water filtered was $29-37$ L. All samples were transferred into $50 \mathrm{~mL}$ bottles, preserved with 5\% formalin and transported back to the laboratory. Laboratory work involved the used Sedgewick-Rafter counting chamber, following the standard protocol as suggested by Marsden (1992). Water sample (1 mL) was transferred onto the chamber and observed using a compound microscope (Olympus SZ51) with either 10 or 40 magnification. Zooplankton groups were identified to the lowest possible taxon using standard zooplankton identification keys of Hasle et al. (1996), Johnson and Allen (2005) and Al-Kandari et al. (2009). Cell enumeration for each taxon was carried out simultaneously, following methods by Goswami (2004).

\section{Time series analysis}

This study used monthly data from May 2017 to April 2018. Since the data are indexed in time order, the time series analyses such as the Granger causality test can be applied to these data.

\section{Unit root test}

Before testing for the causality, a stationary test is necessary. Thus, the unit root test to examine the stationarity of the variables is conducted (Glynn et al., 2007). The Augmented Dickey-Fuller (ADF) test 
was used to measure the robustness. The ADF test should suggest that all variables are integrated at level denoted as I (0) or order one denoted as I (1) to validate the use of the Granger causality test.

\section{Granger causality test}

The study followed Toda and Yamamoto (1995) procedure to test for Granger causality. In explaining the core dynamics of ecological systems, Granger causality can be used to untangle direct and feedback relationship between the different components of the system (Detto et al., 2012). The bivariate relationship between the total number of Acetes with the total number of zooplankton and selected water quality parameters such as surface water temperature, salinity, turbidity, dissolved oxygen (DO), pH, depth, TSS and chlorophyll $a$ are examined. The Granger causality test examines whether a variable $X$ is the cause of another variable $Y$ (the aggregation of sergestid shrimp Acetes). The Vector Autoregressive (VAR) model of the two time series are given as

$$
\begin{aligned}
& y_{\mathrm{t}}=a_{0}+a_{1} y_{t-1}+\cdots+a_{p} y_{t-p}+b_{1} x_{t-1}+\cdots+b_{p} x_{t-p}+u_{t} \\
& x_{\mathrm{t}}=a_{0}+c_{1} x_{t-1}+\cdots+c_{p} x_{t-p}+d_{1} y_{t-1}+\cdots+d_{p} y_{t-p}+v_{t}
\end{aligned}
$$

where $x$ represents the water quality parameters or the total number of zooplankton and $y$ represents the total number of Acetes. Using the null hypothesis, $H_{0}: b_{1}=b_{2}=\cdots=b_{p}=0$ or $H_{0}: d_{1}=d_{2}=\cdots=d_{p}=0$, a rejection of the null implies there is Granger causality.

\section{Optimal lag selection}

The estimation of the VAR model requires appropriate lag length (Glynn et al., 2007). For this case, the choice of lag length was based on Akaike Information Criterion (AIC). The appropriate lag length for the VAR models is estimated at the level. The appropriate lag is selected according to AIC for every model. Each model has to undergo a serial correlation test in its residual. The Portmanteau test for serial correlation is used with the null hypothesis of no autocorrelation in the residuals. The next VAR model with $p+m$ lags is modelled where $p$ is the number of lags found in the previous analysis and $m$ represents the maximum order of integration that occurred in the process.

\section{Granger causality F-statistics}

After the new VAR models are constructed, Granger causality using Wald test (F-test) for linear restriction is tested. The Wald statistics is asymptotically chi-square distributed under the null hypothesis. Rejection of this hypothesis supports the presence of Granger causality.

\section{RESULTS AND DISCUSSION}

Three species namely Acetes erythraeus, A. serrulatus and $A$. japonicus were identified in Miri coastal water and their descriptions agreed well with diagnosis and illustrations provided by Pathansali (1966), Omori (1975), Amin et al. (2011) and Vereshchaka et al. (2016). The morphological descriptions of these species have been described by Othman et al. (2020). Male A. erythraeus had 15 to 16 segments of the antennular flagellum, a single clasping spine with tubercles and petasma with one large hook followed by three to four small hooks. Female $A$. erythraeus had 12 to 16 segments of lower antennular flagellum while the third thoracic sternite has a trapezoid shape as shown in Figure 2.

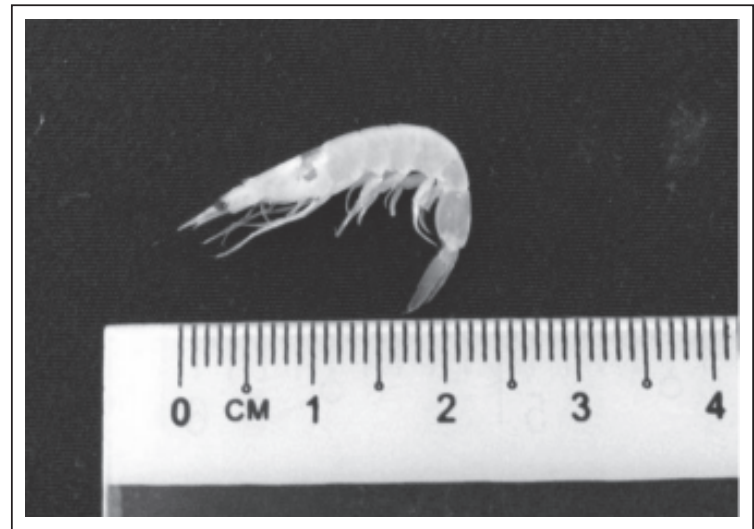

Fig. 2. Whole body of Acetes erythraeus.

Male $A$. serrulatus was identified with 11 segments of the antennular flagellum and two clasping spines with different lengths while female $A$. serrulatus was identified based on the third thoracic sternite with a curve at the middle as shown in Figure 3.

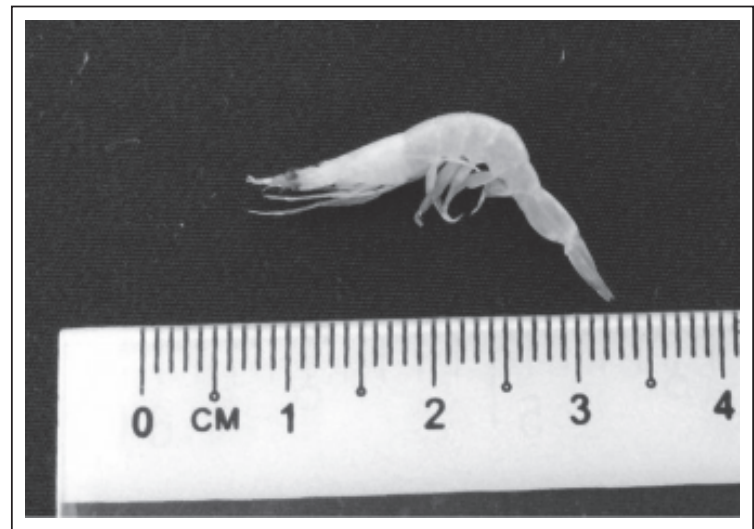

Fig. 3. Whole body of $A$. serrulatus.

Only male $A$. japonicus was found in Miri coastal water with 11 segments of the lower antennular flagellum, two different lengths of clasping spines with tubercles on the surface and petasma shaped like a bulb with numbers of small hooks. 
Table 3. Range of selected water quality parameters for every station in Miri coastal water, Sarawak

\begin{tabular}{lcccc}
\hline & Station 1 & Station 2 & Station 3 & Station 4 \\
\hline Temperature $\left({ }^{\circ} \mathrm{C}\right)$ & $29.0-31.5$ & $27.0-32.0$ & $26.9-32.0$ & $27.3-33.2$ \\
Salinity $(\mathrm{PSU})$ & $5-35$ & $5-35$ & $5-35$ & $17-35$ \\
Turbidity $(\mathrm{mg} / \mathrm{L})$ & $22.22-530.67$ & $9.23-502.50$ & $10.99-392.67$ & $10.67-492.33$ \\
Dissolved Oxygen $(\mathrm{mg} / \mathrm{L})$ & $4.48-7.22$ & $5.31-7.05$ & $4.92-7.02$ & $5.09-7.31$ \\
$\mathrm{pH}$ & $7.03-8.32$ & $7.07-8.23$ & $7.12-8.19$ & $6.98-8.18$ \\
TSS $(\mathrm{mg} / \mathrm{L})$ & $52-537$ & $37-343$ & $36-561$ & $26-335$ \\
chlorophyll $a\left(\mathrm{mg} / \mathrm{m}^{3}\right)$ & $0.6632-2.7219$ & $0.4262-2.2231$ & $0.6119-2.3116$ & $0.6597-2.4528$ \\
\hline
\end{tabular}

Table 4. Unit root test for all variables using ADF test

\begin{tabular}{lcc}
\hline & t-Statistics in levels & t-Statistics in first difference \\
\hline Temperature $\left({ }^{\circ} \mathrm{C}\right)$ & -2.336 & $-4.984^{*}$ \\
Salinity $(\mathrm{PSU})$ & -2.831 & $-8.411^{*}$ \\
Turbidity $(\mathrm{mg} / \mathrm{L})$ & -1.819 & $-6.975^{*}$ \\
Dissolved Oxygen $(\mathrm{mg} / \mathrm{L})$ & -1.198 & $-4.072^{*}$ \\
$\mathrm{pH}$ & -3.277 & $-7.117^{*}$ \\
TSS $(\mathrm{mg} / \mathrm{L})$ & -3.267 & $-8.029^{*}$ \\
chlorophyll a $\left(\mathrm{mg} / \mathrm{m}^{3}\right)$ & -1.942 & $-5.216^{*}$ \\
Number of Acetes & -3.422 & $-3.471^{*}$ \\
Number of zooplankton & -1.714 & $-3.204^{*}$ \\
\hline
\end{tabular}

* Significant at $5 \%$ level.

\section{Water quality parameters}

The values of selected water quality parameters for every station measured throughout the year from May 2017 until April 2018 are shown in Table 3.

\section{Unit root test}

All variables undergo stationary testing at levels and their first difference. Table 4 shows the ADF test result for all variables.

The ADF test from Table 4 shows that all variables are non-stationary and are stationary at the first difference in significance level 5\%. Therefore the data series can be characterized as I(1).

\section{Optimal lag selection}

The lag length for each variable in the VAR model was estimated using AIC. Table 5 show the result of this test.

Table 5. Lag length for all variables in the VAR model

\begin{tabular}{lc}
\hline & Lag, $p$ \\
\hline Temperature $\left({ }^{\circ} \mathrm{C}\right)$ & 4 \\
Salinity (PSU) & 1 \\
Turbidity $(\mathrm{mg} / \mathrm{L})$ & 3 \\
Dissolved Oxygen $(\mathrm{mg} / \mathrm{L})$ & 4 \\
$\mathrm{pH}$ & 2 \\
TSS $(\mathrm{mg} / \mathrm{L})$ & 1 \\
chlorophyll a $\left(\mathrm{mg} / \mathrm{m}^{3}\right)$ & 0 \\
Number of Acetes & 1 \\
Number of zooplankton & 2 \\
\hline
\end{tabular}

\section{Granger causality VAR model and F-statistics}

The last step in the analysis is to create VAR models with $p+m$ lags and test Granger causality using the Wald test for linear restrictions. The number of lags $p$ were taken from the values in Table 5 and are increased by 1 because all variables are I(1). The presence of Granger causality between the water quality parameter and number of zooplankton towards the number of Acetes are tested at each station. There are 22 equations involved in the test as indicated in Table 6.

There was evidence of a causal relationship of salinity to the number of Acetes at Station 2 as indicated in Table 7. There was also a causal relationship of DO to the number of Acetes in Station 1. These findings show that the current number of Acetes in Station 2 and Station 1 can be explained by the past values of the Acetes, salinity and DO at the area. This was in line with the concept of interaction between biotic and abiotic factors which is important for the survival of a species and the overall health of an ecosystem (Molles \& Simon, 2019).

There was evidence of a causal relationship of the number of Acetes to $\mathrm{pH}$ as indicated in Table 8. $\mathrm{pH}$ is one of the parameters that inter-dependent and among the important water parameters to shrimp complex life cycle. Bechmann et al. (2011) had reported that variations of $\mathrm{pH}$ did not affect the survival of shrimps but lower $\mathrm{pH}$ caused significant delays in zoeal progression (development time). 
Table 6. The VAR models for the Granger causality test

\begin{tabular}{|c|c|c|}
\hline Dependent Variables, $y$ & $\begin{array}{l}\text { Independent } \\
\text { Variables, } x\end{array}$ & Equations \\
\hline Number of Acetes & Temperature & $y_{t}=0.05 y_{t-1}+36.34 x_{t}-135.43 x_{t-1}+54.93 x_{t-2}-21.96 x_{t-3}-36.63 x_{t-4}+\mu_{t}$ \\
\hline Number of Acetes & Salinity & $y_{t}=-0.47 y_{t-1}+12.2 x_{t}-15.89 x_{t-1}+\mu_{t}$ \\
\hline Number of Acetes & Turbidity & $y_{t}=-0.89 y_{t-1}-1.66 x_{t}-1.22 x_{t-1}-0.69 x_{t-2}-0.60 x_{t-3}+\mu_{t}$ \\
\hline Number of Acetes & Dissolved Oxygen & $y_{t}=-0.06 y_{t-1}+211.8 x_{t}+26.92 x_{t-1}+75.59 x_{t-2}-91.22 x_{t-3}+386.92 x_{t-4}+\mu_{t}$ \\
\hline Number of Acetes & $\mathrm{pH}$ & $y_{t}=-0.42 y_{t-1}+572.3 x_{t}-336.5 x_{t-1}-46.3 x_{t-2}+\mu_{t}$ \\
\hline Number of Acetes & TSS & $y_{t}=-0.26 y_{t-1}-0.95 x_{t}+0.34 x_{t-1}+\mu_{t}$ \\
\hline Number of Acetes & chlorophyll a & $y_{t}=-0.39 y_{t-1}+125.55 x_{t}+\mu_{t}$ \\
\hline Temperature & Number of Acetes & $y_{t}=0.09 y_{t-1}+0.63 y_{t-2}-0.14 y_{t-3}+0.17 y_{t-4}+0.001 x+0.005 x_{t-1}+\mu_{t}$ \\
\hline Salinity & Number of Acetes & $y_{t}=0.15 y_{t-1}+0.02 x+0.02 x_{t-1}+\mu_{t}$ \\
\hline Turbidity & Number of Acetes & $y_{t}=-0.84 y_{t-1}-0.53 y_{t-2}-0.36 y_{t-3}-0.37 x-0.44 x_{t-1}+\mu_{t}$ \\
\hline Dissolved Oxygen & Number of Acetes & $y_{t}=-0.16 y_{t-1}-0.4 y_{t-2}+0.24 y_{t-3}-1.67 y_{t-4}+0.004 x+0.00002 x_{t-1}+\mu_{t}$ \\
\hline $\mathrm{pH}$ & Number of Acetes & $y_{t}=0.49 y_{t-1}-0.01 y_{t-2}+0.0007 x+0.0003 x_{t-1}+\mu_{t}$ \\
\hline TSS & Number of Acetes & $y_{t}=0.03 y_{t-1}-0.38 x-0.16 x_{t-1}+\mu_{t}$ \\
\hline chlorophyll a & Number of Acetes & $y_{t}=0.0009 x+0.0008 x_{t-1}+\mu_{t}$ \\
\hline Number of Acetes & $\begin{array}{l}\text { Number of } \\
\text { Centropages }\end{array}$ & $y_{t}=-0.3 y_{t-1}+4.17 x_{t}+8.81 x_{t-1}-13.53 x_{t-2}+\mu_{t}$ \\
\hline Number of Acetes & $\begin{array}{l}\text { Number of } \\
\text { Euterpina }\end{array}$ & $y_{t}=-0.39 y_{t-1}+19.14 x_{t}+34.9 x_{t-1}-13.63 x_{t-2}+\mu_{t}$ \\
\hline Number of Acetes & $\begin{array}{l}\text { Number of } \\
\text { Oithona rigida }\end{array}$ & $y_{t}=-0.67 y_{t-1}-8.41 x_{t}+25.37 x_{t-1}-15.33 x_{t-2}+\mu_{t}$ \\
\hline Number of Acetes & Number of Oncaea & $y_{t}=-0.38 y_{t-1}+12.52 x_{t}+11.57 x_{t-1}-16.86 x_{t-2}+\mu_{t}$ \\
\hline Number of Centropages & Number of Acetes & $y_{t}=0.53 y_{t-1}-0.27 y_{t-2}+0.001 x_{t}-0.006 x_{t-1}+\mu_{t}$ \\
\hline Number of Euterpina & Number of Acetes & $y_{t}=0.37 y_{t-1}-0.11 y_{t-2}+0.0005 x_{t}-0.001 x_{t-1}+\mu_{t}$ \\
\hline Number of Oithona rigida & Number of Acetes & $y_{t}=0.77 y_{t-1}-0.41 y_{t-2}-0.003 x_{t}-0.02 x_{t-1}+\mu_{t}$ \\
\hline Number of Oncaea & Number of Acetes & $y_{t}=0.4 y_{t-1}-0.18 y_{t-2}+0.005 x_{t}-0.003 x_{t-1}+\mu_{t}$ \\
\hline
\end{tabular}

Table 7. The F-value of the Granger causality test using water quality parameter as independent variable and number of Acetes as the dependent variable

\begin{tabular}{lcccc}
\hline \multirow{2}{*}{ Parameter } & \multicolumn{3}{c}{ Water quality Parameter $\rightarrow$ Number of Acetes } \\
\cline { 2 - 4 } & Station 1 & Station 2 & Station 3 & Station 4 \\
\hline Temperature & 1.951639 & 4.200204 & 1.353954 & 3.149002 \\
Salinity & 0.434895 & $16.25672^{*}$ & 3.119200 & 4.147075 \\
Turbidity & 0.732178 & 1.642284 & 0.831831 & 3.293736 \\
Dissolved Oxygen & $13.13727^{*}$ & 2.590945 & 1.332515 & 4.254184 \\
pH & 0.632646 & 3.880500 & 7.647426 & 2.300763 \\
TSS & 1.427839 & 6.482468 & 2.179579 & 1.186765 \\
chlorophyll a & 0.171115 & 2.548306 & 3.487730 & 0.827514 \\
\hline
\end{tabular}

* Significant at $5 \%$ level.

Granger causality emerged between the abundance of Acetes and DO at Station 1 and 3. Station 1 and 3 are located near the rivers, lined with mangrove vegetation and they share the same pattern of interaction between Acetes shrimp abundance with turbidity, DO and TSS. Using the Granger causality test, results showed that when Acetes blooms happened, the three parameters were affected.
Turbidity could be caused by the wastes (i) from animals, (ii) those originated from the marine vessels or (iii) transported from the land, or organic matters in the water column, microscopic microorganisms, planktons, inorganic matters or sediment (Yap et al., 2011; Boyd, 2015). Bloom of Sergestid shrimps alone could not cause the turbidity and high concentration of TSS, because it had been reported that freshwater 
Table 8. The F-value of the Granger causality test using the number of Acetes as the independent variable and water quality parameter as the dependent variable

\begin{tabular}{lcccc}
\hline \multirow{2}{*}{ Parameter } & \multicolumn{4}{c}{ Number of Acetes $\rightarrow$ Water quality Parameter } \\
\cline { 2 - 4 } & Station 1 & Station 2 & Station 3 & Station 4 \\
\hline Temperature & 1.06421 & 0.19507 & 3.42072 & 1.24362 \\
Salinity & 0.764683 & 0.166089 & 0.231142 & 3.058537 \\
Turbidity & $20.84289^{*}$ & 5.527854 & $11.33283^{*}$ & 5.541686 \\
Dissolved Oxygen & $8.210271^{*}$ & 2.057743 & $284.6227^{*}$ & 7.497724 \\
pH & $8.601894^{*}$ & 1.122728 & 0.561111 & 2.521063 \\
TSS & $95.19428^{*}$ & 3.620863 & $2559.298^{*}$ & 2.474972 \\
chlorophyll a & 1.632042 & 1.563292 & $28.46673^{*}$ & 0.414039 \\
\hline
\end{tabular}

* Significant at $5 \%$ level.

Table 9. The F-value of the Granger causality test using the number of zooplankton as independent variable and number of Acetes as the dependent variable

\begin{tabular}{llccc}
\hline \multirow{2}{*}{ Zooplankton } & \multicolumn{4}{c}{ Number of zooplankton $\rightarrow$ Number of Acetes } \\
\cline { 2 - 5 } & Station 1 & Station 2 & Station 3 & Station 4 \\
\hline Centropages & 0.087066 & 0.029789 & 0.541095 & 1.133856 \\
Euterpina & 0.950325 & $37.17876^{*}$ & 1.114025 & 0.432902 \\
Oithona rigida & 0.628400 & 1.250231 & $8.583078^{*}$ & 1.226086 \\
Oncaea & 0.028176 & 3.972603 & $6.576559^{*}$ & $6.358389^{*}$ \\
\hline
\end{tabular}

* Significant at $5 \%$ level.

Table 10. The F-value of the Granger causality test using the number of Acetes as independent variable and number of zooplankton as the dependent variable

\begin{tabular}{llccc}
\hline \multirow{2}{*}{ Zooplankton } & \multicolumn{4}{c}{ Number of Acetes $\rightarrow$ Number of zooplankton } \\
\cline { 2 - 5 } & Station 1 & Station 2 & Station 3 & Station 4 \\
\hline Centropages & 1.109250 & 0.263693 & 0.371455 & $7.248615^{*}$ \\
Euterpina & 0.106718 & 2.345940 & 2.764512 & 2.445608 \\
Oithona rigida & $6.468700^{*}$ & 0.328327 & 0.141914 & $7.929168^{*}$ \\
Oncaea & 0.025090 & 3.567029 & 0.591486 & 2.224693 \\
\hline
\end{tabular}

* Significant at $5 \%$ level.

input may also lead to enhanced transportation of organic matters as well as suspended solids from mangrove litter and dissolution of mangrove soil organic matter (Kida et al., 2019).

Plankton are small organisms that dwell in oceans, seas and bodies of freshwater (McManus \& Woodson, 2012). Plankton is composed of viruses, bacteria, phytoplankton, zooplankton and the pelagic larvae of many marine invertebrates and fishes. This group displays a wide range of behavioural capabilities that bridge the transition from being a passive particle to being able to determine the vertical and horizontal position in the ocean (McManus \& Woodson, 2012). The concentration of chlorophyll $a$ is an important indicator to determine the biomass and growth of phytoplankton (Idrus et al., 2017). In this study, there is evidence of a causal relationship of the number of Acetes to chlorophyll $a$ as indicated in Table 8. Aggregation of Acetes may associate with the presence of phytoplankton, as plankton play a key role in the marine food web by transferring the organic energy produced by the unicellular algae to higher trophic levels such as zooplankton and the pelagic stocks (Varghese et al., 2015).

From Table 9, a causal relationship exists based on the number of zooplankton (Euterpina, Oithona rigida and Oncaea) to the number of Acetes at Stations 2, 3 and 4. 
There was also a causal relationship from number of Acetes to the number of zooplankton (Centropages and Oithona rigida) at Stations 1 and 4 as indicated in Table 10. Zooplankton Oithona rigida and Acetes experience bi-directional relationship in terms of abundance with each other. Previous researchers, for example, Omori (1975), Saini et al. (2011) and Saini (2013) claimed that diets of Sergestid shrimps are plankton therefore the abundant of the zooplankton has an influence on the aggregation of shrimps in the area.

\section{CONCLUSION}

A total of three species of Acetes were identified in the coastal water of Miri, Sarawak namely $A$. erythraeus, A. serrulatus and $A$. japonicas. This study also highlighted the ability of the econometrics model (Granger causality test) in describing the interaction between environmental and biological factors towards the abundance of Acetes. From the causality test against 22 different equations, salinity and DO play a significant impact on the number of Acetes in the area whereas Acetes assemblages have shown a significant impact on the water quality parameters (temperature, salinity, turbidity, $\mathrm{pH}$,

TSS and chlorophyll $a$ ). There was also evidence of interaction between zooplankton with the aggregation of Acetes. The study and constant monitoring of Acetes assemblages are very important in assessing the risk of over-capitalization (overexploitation) of Acetes fishery in Sarawak as it is an open-access fishery.

\section{ACKNOWLEDGEMENTS}

This work is supported by UNIMAS-UMS Grant Scheme GL/F07/UMS/06/2017. The authors would like to thank the local people of Batu 1 village and UNIMAS postgraduate students for their kind assistance during sampling trips. Thank you to UNIMAS for laboratory and ICT facilities.

\section{REFERENCES}

Abdullah, M. 2018. Bubuk season is back in Miri. Borneo Post. URL https://www.theborneopost. com/2018/03/05/bubuk-season-is-back-in-miri/ (accessed 11.17.2019)

Abdullah, M. 2019. Bountiful bubuk season good news for Miri belacan makers. Borneo Post. URL https://www.theborneopost.com/2019/03/18/ bountiful-bubuk-season-good-news-for-miribelacan-makers/ (accessed 11.17.2019)
Al-Kandari, M., Al-Yamani, F. \& Al-Rifaie, K. 2009. Marine Phytoplankton Atlas of Kuwait's Waters. Kuwait Institute for Scientific Research, Safat.

Amin, S.M.N., Arshad, A., Ismail, N.H., Idris, M.H., Bujang, J.S. \& Siraj, S.S. 2010. Morphometric variation among the three species of genus Acetes (Decapoda: Sergestidae) in the coastal waters of Malacca, Peninsular Malaysia. Pertanika Journal of Tropical Agriculture Science, 33(2): 341-347.

Amin, S.M.N., Arshad, A., Siraj, S.S. \& Sidik, B.J. 2011. Update on the species composition and distribution of sergestid shrimps (Acetes spp.) in Malaysian waters. Journal of Fisheries and Aquatic Science, 6(7): 761-770.

Amin, S.M.N., Arshad, A., Siraj, S.S., Sidik, B.J. \& Rahman, M.A. 2012. Population biology and stock status of planktonic shrimp Acetes indicus (Decapoda: Sergestidae ) in the coastal waters of Malacca, Peninsular Malaysia. Aquatic Ecosystem Health \& Management, 15(3): 294302.

Aminot, A. \& Rey, F. 2000. Standard procedure for the determination of chlorophyll $a$ by spectroscopic methods. ICES Techniques in Marine Environmental Sciences, 1-17.

Anandkumar, A., Nagarajan, R., Prabakaran, K. \& Rajaram, R. 2017. Trace metal dynamics and risk assessment in the commercially important marine shrimp species collected from the Miri coast, Sarawak, East Malaysia. Regional Studies in Marine Science, 16: 79-88.

Bechmann, R.K., Taban, I.C., Westerlund, S., Godal, B.F., Arnberg, M., Vingen, S., Ingvarsdottir, A. \& Baussant, T. 2011. Effects of ocean acidification on early life stages of shrimp (Pandalus borealis) and mussel (Mytilus edulis). Journal of Toxicology and Environmental Health, 74(7): 424-38.

Boyd, C.E. 2015. Water quality: an introduction. Springer International Publishing, Switzerland.

Calazans, D. 2002. Seasonal larval composition and abundance of shrimps in the surrounding area of the Patos Lagoon Mouth. Nauplius, 10(2): $111-120$

Chen, Y. \& Chen, I. 2002. Effects of temperature and salinity on the metamorphosis of nauplius of a planktonic shrimp Acetes intermedius Omori, 1975. Fisheries Science, 68: 117-122.

Childress, M. 2015. Forecasting a crab fishery using real-time freshwater flow data. Dry Times, 5(2): 5-6.

Chiou, W.D., Wu, C.C. \& Cheng, L.Z. 2000. Spatiotemporal distribution of sergestid shrimp Acetes intermedius in the coastal waters of southwestern Taiwan. Fisheries Science, 66: 1014-1025. 
Detto, M., Molini, A., Katul, G., Stoy, P., Palmroth, S. \& Baldocchi, D. 2012. Causality and persistence in ecological systems: A nonparametric spectral Granger causality approach. The American Naturalist, 179 (4): 524-535.

Ee, T.F. \& Zae, L.V. 2010. A study of coastal areas in Miri, Sarawak, in: Conference of Natural Resources and Green Technology, Sarawak, 2010.

Glynn, J., Perera, N. \& Verma, R. 2007. Unit root tests and structural breaks: A survey with applications. Journal of Quantitative Methods for Economics and Business Administration. 3(1): 63-79.

Goswami, S.C. 2004. Zooplankton Methodology, Collection \& Identification - a field Manual. National Institute of Oceanography, Goa.

Hasle, G.R., Syvertsen, E.E., Stedinger, K.A., Tangen, K. \& Tomas, C.R. 1996. Identifying Marine Diatoms and Dinoflagellates. Academic Press, California.

Hassan, R. \& Othman, M.N.A. 2021. Molecular analysis of sergestid shrimp Acetes spp. from coastal water of Sarawak, Malaysian Borneo using CO1 gene Sequence. Current Applied Science and Technology, 21(4): 629-636.

Idrus, F.A., Chong, D.M., Abd Rahim, M.S., Basri, M.M. \& Musel, J. 2017. Physicochemical parameters of surface seawater in Malaysia Exclusive Economic Zones off the coast of Sarawak. Borneo Journal of Resource Science and Technology, 7(1): 1-10.

Johnson, W.S. \& Allen, D.M. 2005. Zooplankton of the Atlantic and Gulf coasts. The Johns Hopkins University Press, Maryland.

Kida, M., Tanabe, M., Tomotsune, M., Yoshitake, S., Kinjo, K., Ohtsuka, T. \& Fujitake, N. 2019. Changes in dissolved organic matter composition and dynamics in a subtropical mangrove river driven by rainfall. Estuarine, Coastal and Shelf Science, 223: 6-17

Marsden, T. 1992. Exploring a rural sociology for the fordist transition incorporating social relations into economic restructuring. Sociologia Ruralis, 32: 209-230.

McManus, M.A. \& Woodson, C.B. 2012. Plankton distribution and ocean dispersal. Journal of Experimental Biology, 215(6): 1008-1016.

Moksness, E., Dahl, E. \& Storrup, J. 2013. Global Challenges in integrated coastal management. John Wiley \& Sons Ltd, United Kingdom.

Molles, M.C. \& Simon, A.S. 2019. Ecology: Concepts and Applications. 8th Ed. Mc Graw Hill Education, New York.
Musel, J., Anuar, A., Mohamad, S., Mustapa, N., Hassan, M.H., Rajali, H. \& Anuar, A. 2019. Morphometric relationship and the spawning season of Acetes intermedius from the coast of Miri Sarawak, Northwestern Borneo. AACL Bioflux, 12(2), 457-471.

Obatitor, A.E. 2014. The importance of coastal environment in promoting human health and wellbeing. URL http://hdl.handle.net/10062/43458 (accessed 11.17.2019)

Omori, M. 1975. The systematics, biogeography, and fishery of epipelagic shrimps of the Genus Acetes (Crustacea, Decapoda, Sergestidae). Bulletin of the Ocean Research Institute, 7: 186.

Othman, M.N.A., Hassan, R. \& Ann, C.C. 2020. Checklist of sergestid shrimps, Acetes (Decapoda: Sergestidae) from selected sites along the coastal water of Sarawak, Malaysia. Malayan Nature Journal 2020, 72(1): 121-131.

Pathansali, D. 1966. Acetes (Sergestidae) from the Malay Peninsula. Bulletin of the National Museum of Singapore, 33(18): 59-63.

Perry, R. 2003. A guide to the marine plankton of Southern California. 3rd Edition UCLA. Marine Science Center Ocean GLOBE. URL https:// dornsife.usc.edu/assets/sites/291/docs/ HABWatch/3_Plankton_Guide_2010rev.pdf (accessed 11.17.2019).

Ringgit, M. 2019. Bubuk seller uses social media to boost sales. New Sarawak Tribune. URL https:// www.newsarawaktribune.com.my/bubuk-selleruses-social-media-to-boost-sales/ (accessed 11.17.2019).

Saini, M., Arshad, A., Amin, S.M.N. \& Idris, M.H. 2011. Growth, mortality and recruitment of planktonic shrimp, Acetes intermedius in the coastal waters of Bintulu, Sarawak East Malaysia. Journal of Fisheries and Aquatic Science, 6(7): 780-787.

Saini, M. 2013. Feeding habits, recruitment and status of sergestid shrimps (Acetes intermedius Omori) stock in Bintulu, Sarawak (Master). Universiti Putra Malaysia.

Scannell, P.W. \& Jacobs, L.L. 2001. Technical Report: No. 01-06 Effects of Total Dissolved Solids on Aquatic Organisms. URL http://www.adfg.alaska. gov/static/home/library/pdfs/habitat/01_06.pdf (accessed 11.17.2019)

Simoes, S.M., Castilho, A.L., Fransozo, A., Negreiros-Fransozo, M.L. \& Costa, R.C.D. 2013. Distribution related to temperature and salinity of the shrimps Acetes americanus and Peisos petrunkevitchi (Crustacea: Sergestoidea) in the south-eastern Brazilian littoral zone. Journal of Marine Biological Association of the United Kingdom, 93(3): 753-759. 
Srinivasan, V., Natesan, U. \& Parthasarathy, A. 2013. Seasonal variability of coastal water quality in Bay of Bengal and Palk Strait, Tamilnadu, Southeast Coast of India. Brazilian Archives of Biology and Technology, 56: 875-884.

Stephenie, D.K., Chen, C.A., Hassan, R., Mustafa, S., Shapawi, R. \& Halid, N.F.A. 2021. Analysis of past 26 years landing data to understand the status of Acetes spp. population in Malaysia. IOP Conference Series: Earth and Environmental Science.

Toda, H.Y. \& Yamamoto, T. 1995. Statistical inferences in vector autoregressions with possibly integrated processes. Journal of Econometrics, 66: 225-250.
Varghese, M., Thomas, V.J. \& Susan, V. 2015. Collection and estimation of zooplankton. URL eprints.cmfri.org.in/10410/1/05_Molly_ Varghese2.pdf (accessed 08.03.2019).

Vereshchaka, A.L., Lunina, A.A. \& Jørgen, O. 2016. Phylogeny and classification of the shrimp genera Acetes, Peisos, and Sicyonella (Sergestidae/ : Crustacea/ : Decapoda). Zoological Journal of the Linnean Society, 177: 353-377.

Yap, C.K., Chee, M.W., Shamarina, S., Edward, F.B., Chew, W. \& Tan, S.G. 2011. Assessment of surface water quality in the Malaysian coastal waters by using multivariate analyses. Sains Malaysiana, 40(10): 1053-1064. 
